九州大学学術情報リポジトリ

Kyushu University Institutional Repository

\title{
Conceptual Framework of Development of Quality Culture in Indonesian Construction Company
}

Andhika, Rully

Department of Civil Engineering, Faculty of Engineering, Universitas Indonesia

Latief, Yusuf

Department of Civil Engineering, Faculty of Engineering, Universitas Indonesia

https://doi.org/10.5109/2740971

出版情報 : Evergreen. 7 (1)，pp.144-149，2020-03. 九州大学グリーンテクノロジー研究教育センター バージョン:

権利関係 : 


\title{
Conceptual Framework of Development of Quality Culture in Indonesian Construction Company
}

\author{
Rully Andhika ${ }^{1, *}$, Yusuf Latief ${ }^{2}$ \\ ${ }^{1}$ Department of Civil Engineering, Faculty of Engineering, Universitas Indonesia \\ ${ }^{2}$ Department of Civil Engineering, Faculty of Engineering, Universitas Indonesia \\ *Author to whom correspondence should be addressed: \\ E-mail: rully.a.karim@gmail.com
}

(Received November 5, 2019; Revised February 28, 2020; accepted March 10, 2020).

\begin{abstract}
The Quality Management System (QMS) implementation by Big-Grade construction companies in Indonesia is still considered not optimum. This is evidenced by a large number of construction failures on large-scale projects. Whereas the Indonesian government has required all Big-Grade contractors to have ISO-9001 certification. Previous studies stated that the implementation of QMS in an organization must pay attention to the organization's culture. The purpose of this research is to formulate a Conceptual Framework that can identify the processes needed for the development of Quality Culture within a construction company by referring to the existing cultures and the required QMS standards.
\end{abstract}

Keywords: Quality Culture; Construction Organization Culture

\section{Introduction}

The construction world in Indonesia some time ago was filled with news about construction failures. Recorded for 7 months from the end of 2017 to February 2018, there have been 14 cases of construction failures that claimed casualties and fatalities. Responding to that, Makarim ${ }^{1)}$, in his writing on local newspaper (Kompas) on 2 April 2018, stated as follows: "The question is: how often do the construction or building failures occur in Indonesia? The answer is: often, and almost certainly will increase! Recent reports including collapses of a toll girder cranes in the Railroads Construction Project, and a hospital in Surabaya, the fall of girder on several toll road overpass projects and the hollow structural section in the Housing Tower Project, the landslide of the Airport underpass, and the accident in the LRT construction project, and at the Indonesia Stock Exchange building, Jakarta showed only a small part of the phenomenon". Points to be noted is that most projects that experienced construction failures were carried out by Big-Grade contractors, some of whom even repeated for several times. Whereas one of the requirements to become a BigGrade Contractor in Indonesia is to have ISO 9001 certification. So, it is certain that the contractors who made these building failures are IS0 9001 certified.

If the construction failure causes fatalities, the company possibly loses working time, requires cost for repairing the damage and replacing broken goods and materials, experiences decrease on the output due to the disruption of the production process, must provide welfare benefits for the injured persons and wages of the injured workers despite their inability to work, experiences reduction on profitability due to the disruption of the production; and gets risk on company's reputation ${ }^{2}$.

Based on several studies, Hoonakker, et al. ${ }^{3)}$ stated that during the past decades, the construction industry, compare to other industries, has got many criticisms for its bad performances and productivity. Jince ${ }^{4)}$ also stated that based on Haupt and Whiteman (2004), and Low and Hong (2005), historically the construction industry does not like to deal with changes, which can be seen from the slower ISO 9001 implementation, particularly in developing countries. And in the preliminary study on the construction projects quality management implementation in Malaysia ${ }^{5)}$, some points that can be concluded are: ISO certification is mainly only for the purpose of marketing, and the quality management implementation is only to meet contractual obligations instead of to satisfy the client's needs.

As cited in Hoonakker ${ }^{3)}$, a study in Hong Kong conducted by Tam et al. (2000), showed that since seven years after ISO 9000 quality system had been implemented, it has been a requirement for contractors who wanted to be a bidder on housing projects in Hong Kong. Yet, the quality level, in general, has not significantly improved and the expected continuous improvement had not been met. Based on the analysis of the additional data, the authors suggested that the biggest constraint of quality management implementation in construction industry is the culture existing in the 
construction companies. Mandinyenya and Douglas in 2014, who studied several social enterprises in Cambodia, stated that giving careful consideration to the cultural dimension would help in removing cultural barriers ${ }^{6)}$.

As stated by Willar ${ }^{7}$, having a certification of ISO 9001 does not guarantee that a construction company will implement a Quality Management System (QMS) effectively. Indeed it requires a cultural shift by adopting a new culture that focuses on achieving greater customer satisfaction, a total change in organizational focus, and improvement in all levels of operational processes within organizations.

The main objective of this research is to study the strategies needed for the development of Quality Culture in Indonesian construction companies, by paying attention to the existing culture and ISO 9001 standard as regulated by the Indonesian Government. The factors that determine the development processes were identified using Structural Equation Modelling.

\section{Quality Culture}

As cited in Willar et al. ${ }^{8}$, Rumane in 2011 stated that the construction quality failures has become a worldwide problem, based on the results of a construction quality survey conducted by FIDIC. And as cited in Cronemyr et al. ${ }^{9)}$, Eriksson et al. (2016) stated that globalization, digitalization, and acceleration of change require organizations to become more agile and make innovation and processes improvement continuously. Furthermore, Henri (2006) in Cronemyr et al. ${ }^{9}$ ) stated that today, customers can search and compare products and services from around the world, and when they are not satisfied they can easily inform all their fellow consumers about the problems e.g. quality through social media. Therefore, managers must seek for a new approach to management of quality, which in this case, they should explore how their organizations can create a strong culture to give a priority on quality, one of the most important challenges that organizations will face in the future. And based on several previous studies, Willar et al. ${ }^{10)}$ stated that culture in construction organizations is a major factor that determines the success of QMS implementation.

There are various definitions of culture, but in general, they refer to "the patterns of order, material or behavior which have been adopted by a community as the common ways of solving problems"11). In 1999, Ahmed et al. suggested that "culture may include all the institutionalized ways and the implicit beliefs, norms, values and premises which emphasize and affect behavior"11). Schein stated that culture is best conceptualized as shared, tacit assumptions that have come to be taken for granted and determined the peoples' daily behavior ${ }^{12)}$.

Gryna et al. in 2007 as cited in Mahmood \& Mohammed ${ }^{11)}$, specified quality culture as "the pattern of habits, beliefs, and behavior concerning quality". They emphasized that having a supportive quality culture is very important to reach the company's goals in quality. Srinivasan and Kurey defined quality culture as "an environment in which employees do not only follow quality guidelines but also consistently see and hear others taking quality-focused actions, and feel the quality all around them" ${ }^{13)}$. Dellana and Hauser in 1999 suggested that every organization that wants to implement or manage a quality program needs to develop an appropriate quality culture ${ }^{11)}$.

Adapted from Johnson and Scholes (1997), Mahmood \& Mohammed $^{11)}$ suggested various cultural influences that shape the expectations of individuals and stakeholders, which can be grouped into "national culture", "vocational (industry, institution, and profession) culture", and "organizational culture". They also suggested that culture can also be grouped into two different categorizations of elements namely "intrinsic elements" (values, beliefs, and assumptions) and "extrinsic elements" (behavior, norms, rituals, symbols). For the development of quality culture in an organization, Mahmood \& Mohammed (2008) proposed a conceptual framework as presented in fig. 1 .

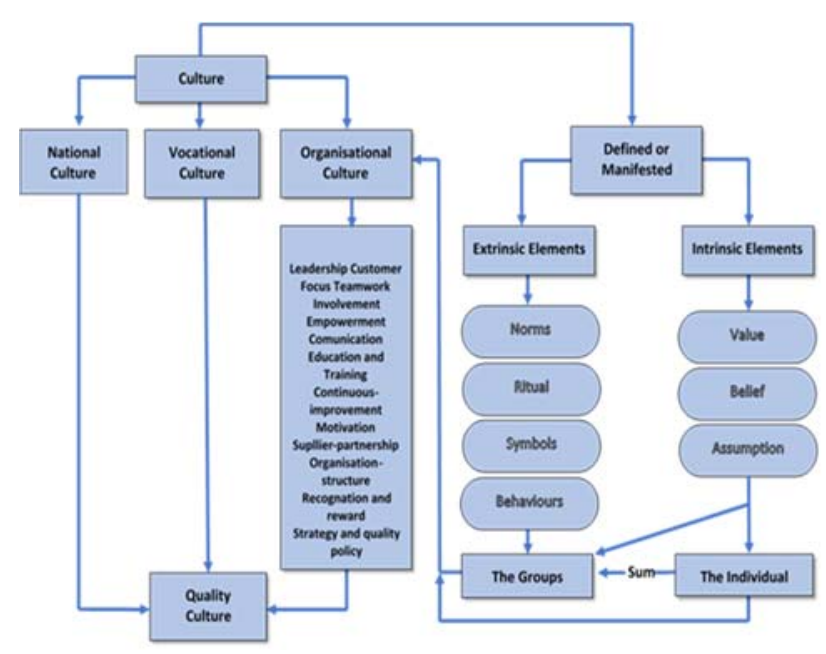

Fig. 1: Conceptual Framework of Quality Culture Development proposed by Mahmood \& Mohammed ${ }^{11)}$.

Based on many studies, Mahmood \& Mohammed $^{11)}$ identified thirteen important dimensions of quality culture that must exist in an organization targeting to implement TQM, which include: "leadership, customer focus, continuous improvement, education and training, teamwork, involvement, empowerment, supplier partnership, recognition and reward, communication, motivation, organization structure, and strategy \& quality policy". And Garvin in 1988, put forward four major cultures of quality namely, culture of inspection, statistical control culture, culture of quality assurance, and strategic quality management culture ${ }^{14)}$. 


\section{Organizational Culture}

Liu \& Jie in 2017 , as cited by Nukic ${ }^{15}$, stated that due to the world economic globalization, organizational culture has become a soft power that is used as a weapon to grab the opportunity and achieve competitiveness sustainability. In relation with the Quality Management System, Willar stated that the current research in the construction management area has evidenced that, quality culture and organization culture in a corporate, are critical success factors for the implementation and maintenance of ISO 9001 quality system ${ }^{8}$.

Many construction companies are ISO 9001 certified companies. But having an ISO 9001 certification cannot guarantee that the company applies the QMS properly, yet it needs a cultural change ${ }^{7)}$. Changing the culture from a "working with a low level of quality and then fixing the defects later" culture, to a "producing right-first-time output" culture, is required in order to implement a quality system application successfully ${ }^{7)}$. As cited in Willar et al. ${ }^{8)}$, Sandholm in 1999 stated that it might be tough for companies to change their old habits and behavior to assimilate a new culture of quality. Also, the Royal Academy of Engineering (RAE) (1996) stated that the challenge of changing the culture in the construction industry is daunting" ${ }^{16)}$. In line with this view, Lakhe, and Mohanty in 1994, concluded that to ensure the successful of Total Quality Management principles application, there must be a major modification of the organization culture, management responsibilities readjustment and full and long-term participation of all stakeholders ${ }^{8)}$.

According to Maull et al. (2001), in Willar et al. ${ }^{10)}$, before attempting to implement total quality management, construction companies should conduct an initial review of their internal culture. Johnson, et al. ${ }^{17)}$ stated that some factors that affect the culture of an organization including national culture (based on Pratt et al., in 1992), societal culture (based on Bloor \& Dawson, in 1994), and organizational environment factors and goals (based on Cooke \& Rousseau, in 1988). Schein in 1986, as cited in Cheung et al. ${ }^{18)}$ suggested that maybe there are several cultures existing within a company: a culture of managerial that is based on occupation, culture of group that comes from geographical closeness, and workers' culture that comes from hierarchical working experiences that are shared together in the community. A company as a one whole organization will have the entire cultures if it has a meaningful shared history. Later on, the 3-level framework of organizational culture was proposed by Schein in $2004^{19)}$ as shown in fig.2.

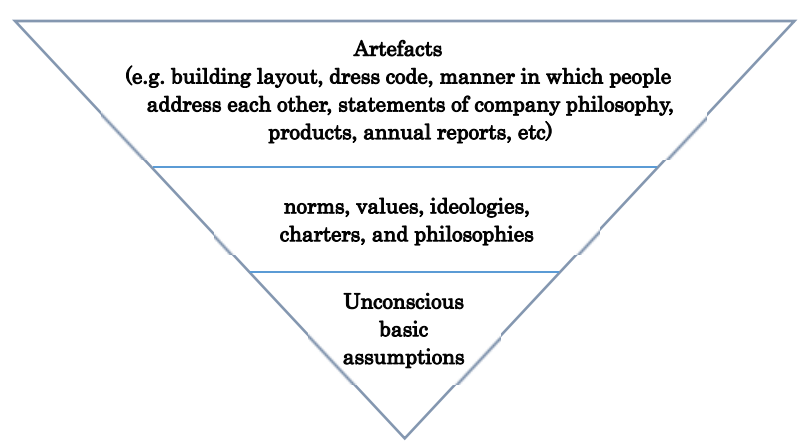

Fig. 2: Three Levels of Organizational Culture by Schein ${ }^{19)}$

Cheung et al. ${ }^{18)}$ have conducted research to identify artifacts in construction companies based on the results of several past studies, and showed 26 artifacts as follows:

1. Clear goals

2. Actions which are matched with the organization's goals

3. A clear approach to succeed

4. Encouragement on information sharing

5. Effective resolution for internal problems

6. Encouragement on interdepartmental collaboration

7. Members' commitment to the team

8. Friendly exchange of opinions and ideas

9. Emphasize on team contributions

10. Trustful atmosphere

11. Negative feedback and criticism acceptance

12. Emphasize on team accountability

13. Input from employees on major decisions

14. Participation of employees in decision-making

15. Values given to employees' ideas

16. Openness to alternative solutions

17. Encouragement on creative and innovative ideas

18. Acceptance on adventurous ideas for sustaining competitiveness

19. Allocation of resources for innovative ideas implementation

20. Clear performance standards

21. Guidance for performance improvement

22. Emphasize on a good performance

23. Reward and recognition to performance

24. Emphasize on the reward instead of punishment

25. Performance-based rewards

26. Equitable reward

\section{National Culture and Occupational / Professional Culture}

Based on Schein (1992), Green (1988), and Hofstede, (1998), Nukic ${ }^{15)}$ suggested that although culture is a collective values and behavior shared by the members of the group, national cultures vary particularly on the fundamental values level, while organizational cultures tend to work on the level of custom practices that can be more controllable. So, national culture is influencing organizational culture. And as stated by A. Mardani, and M. Kazemilari in 2012 20), cultural influences not only 
come from organization culture but also from national culture.

Chen, Podolski, \& Veeraraghavan ${ }^{21)}$ concluded from several literatures that national culture influences various aspects of organization behavior, including risk taking (from Li et al., in 2013), policy of dividend (from Shao et al., in 2010) and earnings quality (from Kanagaretnam et al., in 2011). Consequently, if organizations has a good analysis on and can adapt to their country's culture, their competitiveness will increase ${ }^{22)}$.

Hofstede, Hofstede \& Minkov, in 2010, stated that Hofstede's original model introduced four dimensions to categorize national cultures ${ }^{23)}$, but further research showed the other two new dimensions ${ }^{24)}$. The six dimensions that currently make up Hofstede's framework are: "power distance", "uncertainty avoidance", "individualism", "masculinity", "long-term orientation", and "indulgence" 24,25).

As for organization culture, Schein in 1996 identified three major occupational cultures in organizations ${ }^{12)}$, as follows:

1. The "operators" occupational culture that operates on the levels of line managers and employees who make and produce the products and services,

2. The "engineers" occupational culture that occurs on the levels of technocrats and core designers (e.g. IT programmers, accountants, market researchers, etc.),

3. The "executives" occupational culture that occurs on the levels of top managers and executives.

Dellana and Hauser in 1999, suggested that occupational culture has greater impact over work styles and viewpoints as well as the organization's procedures and policies ${ }^{17)}$. Hansen in 1995 also stated that occupational culture operate across organizational boundaries and is often copied ${ }^{17}$. The occupations that utilize certain technologies even have their own cultures and traditions across national boundaries ${ }^{12)}$. Malmi (1997) and von Meier (1999) stated that "different occupational cultures are expected to interact and conflict with each other", and "organizational culture and occupational culture can also influence each other through the processes of selection and socialization"17).

\section{Quality Management System}

In controlling quality problems in national construction, the government of Indonesia has issued regulations as follows:

1. Undang-Undang Jasa Konstruksi (UUJK) Nomor 18 Tahun 1999 (Law number 18 of 1999) about Construction Services, which has been updated to Law number 2 of 2017.

2. Government Regulations: PP 28 / 2000, PP 29/2000, PP 30/2000, about the description of UUJK articles.

3. Presidential Decree No. 80/2003 concerning Guidelines for Government Goods / Services Procurement.

One of the contents of UUJK Number 18 / 1999 is about the establishment of an Institution named Lembaga Pengembangan Jasa Konstruksi (LPJK) / Construction Services Development Board, which aims to realize a solid, reliable, and highly competitive business structure and good quality results of construction work (lpjk.net).

In 2009 LPJK issued regulations No.12/LPJK of 2009, which explicitly stated that every Grade 7 construction company (the highest grade of company in Indonesia, now named B2) must hold a valid ISO 9001 certification in order to be qualified to work on a big project ${ }^{8}$.

Ramphal in 2015 stated that ISO 9001 is a normative standard that is internationally recognized as a model for the quality management system implementation that can be applied to any type of business ${ }^{26}$. The first version was released in 1987 focusing on the standardization of the organizations' activities through procedures. After a few revisions, in 2015, the latest version was published, with the concept of risk management, organizational context assessment and strengthening leadership roles and responsibilities to achieve the organization's objectives ${ }^{26)}$.

ISO 9001: 2015 is based on Plan-Do-Check-Act cycle, as explained in section 0.1.General, that:

- "This International Standard employs the approach which incorporates the Plan-Do-Check-Act (PDCA) cycle and risk-based thinking.",

- "The approach involves the systematic definition and management of processes, and their interactions, ........... Management of the system as a whole can be achieved using the PDCA cycle with an overall focus on risk-based thinking aimed at taking advantage of opportunities and preventing undesirable results.",

- "The PDCA cycle enables an organization to ensure that its processes are adequately resourced and managed ........"

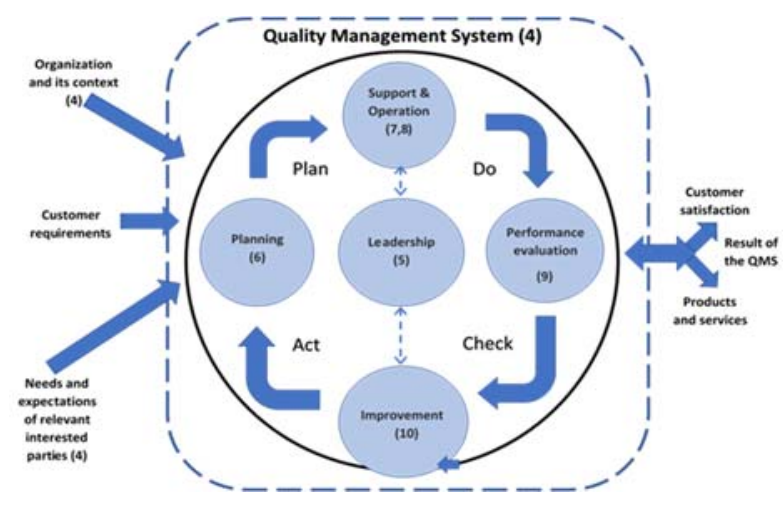

Fig. 3: Representation of the Structure of ISO 9001:2015 in the PDCA cycle 27)

\section{Maturity of Quality}

Wilson $^{19)}$ suggested that attempts to change organizational culture often fails because it is only focused on changing the artifacts, but not changing the fundamental assumptions that specify perceptions, thought processes, feelings, and behavior. $\mathrm{He}^{19)}$ also 
suggested that the process of change towards a quality culture should be carried out with a maturity approach that would be useful as a road map, a framework for prioritizing actions, an assessment tool, and as a common language and a shared vision. That maturity approach, namely Quality Culture Maturity Model will help organizations to assess their current level of quality culture and to determine the actions required to improve it 28). According to Crosby in 1999, one aspect that can distinguish the level of quality management maturity among several corporations is the ISO 9001 certification existence ${ }^{26)}$.

Wilson ${ }^{19)}$ suggested five maturity levels of Quality Maturity Model, as follows: "Ad hoc - Repeatable Defined - Managed - Continuous". $\mathrm{He}^{19)}$ also stated that there are 41 factors to describe what forms "quality culture" that are grouped into eight facets, that are: organization's management; environmental sensing; attributes of learning organization; attitude to change; attitude to quality; leadership; investment in staff; and, alignment.

\section{Conceptual Framework Discussion}

From the literature review above it can be concluded that in Indonesia there are problems with the implementation of construction quality management ${ }^{1)}$. While Willar ${ }^{7)}$ stated that ISO 9001 certification does not guarantee contractors run QMS well. And to run the Quality Management System in total, a cultural change is needed ${ }^{10)}$ as also stated by Henri (2006) in Cronemyr ${ }^{9}$. The quality culture applied in the organization is important to ensure the success of the QMS implementation ${ }^{11) 8}$ ). The QMS required by the Indonesian Government for the implementation of construction is ISO 9001, which is based on the principles of the Plan Do Check Act ${ }^{27)}$.

Based on the problems mentioned above, a study is needed to examine how to implement Quality Culture for construction companies in Indonesia, taking into account the cultures that are already running in the corporate environment. And because the QMS standard required in Indonesia is ISO 9001, the implementation process must also be based on the quality management concept applied by ISO 9001 .

Based on previous research (Schein, 1992; Green, 1988; Hofstede, 1998), Nukic ${ }^{15}$ stated that organizational culture is influenced by National Culture. And Schein in 1996 proposed that there are professional/occupational cultures in every organizations ${ }^{12)}$. Schein in 2004 also stated that organizational culture is embodied in the form of artifacts ${ }^{18)}$ which have been categorized by Cheung et al. ${ }^{18)}$ into 26 artifacts. National culture refers to Hofstede's study which classified different National Cultures from every country in the world into 6 groups ${ }^{24)}$. Related to occupational cultures, Schein in 1996 identified three of them in organizations ${ }^{12)}$.

Based on the literature review, there have not been any studies trying to formulate steps that are necessary to follow in forming an organization culture that applies quality culture by referring to the Plan-Do-Check-Act principle which is the foundation of ISO-9001:2015, by also considering the influence of National Culture and Occupational Culture in Indonesia. The transformation of existing corporate / organization culture towards a quality culture should be applied with a quality management maturity approach. In order to examine this, a conceptual framework of research has been proposed as follows:

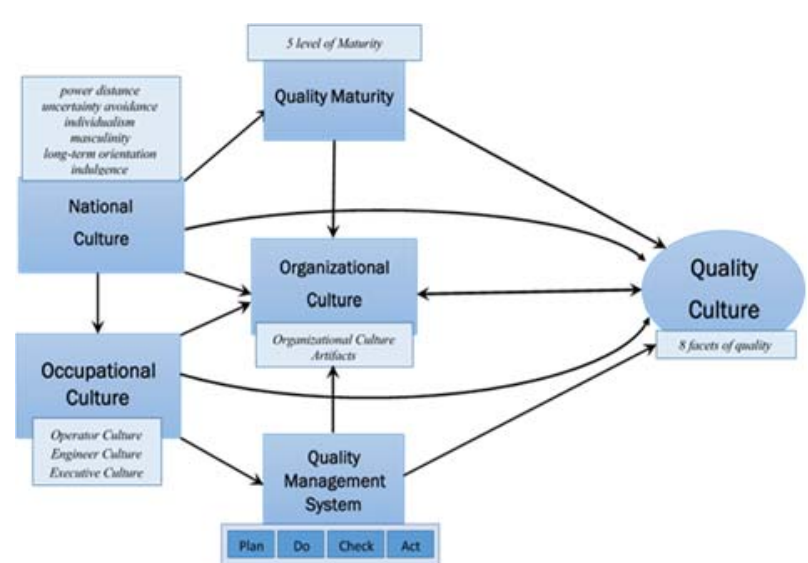

Fig. 4: Conceptual Framework of Development of Quality Culture in Indonesian Construction Company

\section{Conclusion}

To improve the implementation of QMS in Indonesian construction companies, it is necessary to change the corporate culture to a quality culture. Some literature stated that corporate/organization culture is influenced by national culture and occupational/professional culture. So to be able to formulate the steps for change towards a quality culture, the influence of national culture and occupational culture in organizational culture in Indonesian construction companies must be first identified. The transformation of existing corporate/organization culture towards a quality culture will be applied with a quality management maturity approach. And the implementation should be in line with the applied QMS, which is ISO 9001 that uses the PlanDo-Check-Act basic concept. This proposed Conceptual Framework is to formulate a quality culture development process in a construction company by considering the culture that exists in the company/corporate environment with the stages of the maturity level process.

\section{Acknowledgements}

The Authors would like to thank Universitas Indonesia for the financial support provided through PIT 9 funding scheme managed by the Directorate for Research and Public Service Universitas Indonesia under Grant number NKB - 0087/UN2.R3.1/HKP.05.00/2019. 


\section{References}

1) C.A. Makarim, "KRITIK bagi pemimpin artikel opini_kegagalan konstruksi," Kompas.Id, (2018).

2) P. Tungjiratthitikan, "Accidents in thai industry between 2001 and 2017," Evergreen, 5 (2) 86-92 (2018). doi:10.5109/1936221.

3) P. Hoonakker, P. Carayon, and T. Loushine, "Barriers and benefits of quality management in the construction industry: an empirical study," Total Qual. Manag. Bus. Excell., 21 (9) 953-969 (2010). doi:10.1080/14783363.2010.487673.

4) G. Jince, "Impact of Organizational Culture on Total Quality Management in Construction Industries," Politecnico Di Milano, 2015.

5) T. Chin-keng, and H. Abdul-Rahman, "Study of quality management in construction projects," Chinese Bus. Rev., $10 \quad$ (07) (2011). doi:10.17265/1537-1506/2011.07.008.

6) R. Kimura, "“ Social or business ' or " social and business ': problematique of the hybrid structure of community-based cotourism in cambodia," Evergreen, $4 \quad$ (02/03) $\quad 38-49 \quad$ (2017). https://doi.org/10.5109/1929664.

7) D. Willar, "Improving quality management system implementation in Indonesian construction companies," 2012. http://eprints.qut.edu.au/59202/.

8) D. Willar, V. Coffey, and B. Trigunarsyah, "Examining the implementation of iso 9001 in indonesian construction companies," TQM J., 27 (1) 94-107 (2015). doi:10.1108/TQM-08-2012-0060.

9) P. Cronemyr, I. Bäckström, and Å. Rönnbäck, "Quality culture deployment - using behaviours to explain, diagnose and improve a quality culture," Int. J. Qual. Serv. Sci., 9 (3-4) 498-518 (2017). doi:10.1108/IJQSS-02-2017-0008.

10) D. Willar, B. Trigunarsyah, and V. Coffey, "Organisational culture and quality management system implementation in indonesian construction companies," Eng. Constr. Archit. Manag., 23 (2) 114133 (2016). doi:10.1108/ECAM-02-2015-0026.

11) W.Y.W. Mahmood, and A.H. Mohammed, "A conceptual framework for the development of quality culture in the construction industry," Assoc. Res. Constr. Manag. ARCOM 2008 - Proc. 24th Annu. Conf., 1 (January) 247-256 (2008).

12) E.H. Schein, "National and occupational culture factors in safety culture," (2014).

13) P. Patel, D. Baker, R. Burdick, C. Chen, J. Hill, M. Holland, and A. Sawant, "Quality culture survey report," PDA J. Pharm. Sci. Technol., 69 (5) 631-642 (2015). doi:10.5731/pdajpst.2015.01078.

14) F. Alotaibi, and R. Islam, "Total quality management practices, quality culture and contractors' competitiveness," 7 (9) 2642-2649 (2013).

15) I. Šandrk Nukić, "Organizational culture as a determinant of construction companies' competitiveness: case study of croatia," Organ. Cult.,
(2018). doi:10.5772/intechopen.77165.

16) M. Riley, and D. Clare-Brown, "Comparison of cultures in construction and manufacturing industries," Manag. Eng., 17 (July) 149-158 (2001).

17) S.D. Johnson, H.C. Koh, and L.N. Killough, "Organizational and occupational culture and the perception of managerial accounting terms: an exploratory study using perceptual mapping techniques," Contemp. Manag. Res., 5 (4) 317-342 (2009). doi:10.7903/cmr.1931.

18) S.O. Cheung, P.S.P. Wong, and A.W.Y. Wu, "Towards an organizational culture framework in construction," Int. J. Proj. Manag., 29 (1) 33-44 (2011). doi:10.1016/j.ijproman.2010.01.014.

19) F. Wilson, "The quality maturity model: your roadmap to a culture of quality," Libr. Manag., 36 (3) 258-267 (2015). doi:10.1108/LM-09-2014-0102.

20) A. Mardani, and M. Kazemilari, "Relationship between national culture and tqm implementation, case study: iranian multinational electrical manufacturing companies," Asian J. Manag. Res., 3 (1) 291-312 (2012).

21) Y. Chen, E.J. Podolski, and M. Veeraraghavan, "National culture and corporate innovation," Pacific Basin Financ. J., 43 (September 2016) 173-187 (2017). doi:10.1016/j.pacfin.2017.04.006.

22) G. Albayrak, and U. Albayrak, "Organizational culture approach and effects on turkish construction sector," APCBEE Procedia, 9 252-257 (2014). doi:10.1016/j.apcbee.2014.01.045.

23) G. Hofstede, G.J. Hofstede, and M. Minkov, "Cultures and Organizations: Software of the Mind," 3rd ed., Mc Graw Hill, 2010.

24) D. Agodzo, "Six approaches to understanding national cultures: hofstede's cultural dimensions," (November) $\quad 0-11$ doi:10.13140/RG.2.1.5041.8009.

(2015).

25) G. Hofstede, "Dimensionalizing cultures: the hofstede model in context," Online Readings Psychol. Cult., 2 (1) 1-26 (2011). doi:10.9707/23070919.1014.

26) L.S. Sfreddo, G.B.B. Vieira, G. Vidor, and C.H.S. Santos, "ISO 9001 based quality management systems and organisational performance: a systematic literature review," Total Qual. Manag. Bus. Excell., 0 (0) 1-21 (2018). doi:10.1080/14783363.2018.1549939.

27) Badan Standarisasi Nasional, "Standar Nasional Indonesia - ISO 9001:2015 Quality Management System - Requirements," Badan Standarisasi Nasional, Indonesia, 2015.

28) M.-C. Spiak, "Quality Culture Maturity Model: Theoritical Development," Faculty of the National Graduate School \& University of Quality Systems Management, 2012. 